\title{
Primary extra-nodal indolent B-cell lymphoma (small lymphocytic lymphoma/chronic lymphocytic leukemia) of retroperitoneum
}

\author{
Tadashi Terada* \\ Department of Pathology, Shizuoka City Shimizu Hospital, Shizuoka, Japan
}

Received: January 3, 2016

Accepted: March 3, 2016

Online Published: March 25, 2016

DOI: $10.5430 /$ crcp.v3n3p19

URL: http://dx.doi.org/10.5430/crcp.v3n3p19

\begin{abstract}
Primary retroperitoneal malignant lymphoma is rare, and primary retroperitoneal indolent B-cell lymphoma has not been reported. A 64-year-old woman presented anuria. Imaging techniques showed large retroperitoneal mass, and biopsies from it revealed non-Hodgkin indolent B-cell lymphoma (small lymphocytic lymphoma/chronic lymphocytic lymphoma). The tumor appeared retroperitoneal primary and extra-nodal in locations.
\end{abstract}

Key Words: Retroperitoneum, Non-Hodgkin lymphoma, Indolent B-cell neoplasma, Small lymphocytic lymphoma/chronic lymphocytic lymphoma

\section{INTRODUCTION}

Retroperitoneum is a soil of many mesenchymal tumors, but primary retroperitoneal tumors are rare. According to Chakrabarti et al., ${ }^{[1]}$ who examined 71 cases of retroperitoneal masses by fine needle aspiration, showed that out of the 71 cases, 48 cases $(68 \%)$ were neoplasmas which consisted of 35 malignant tumors and 13 benign ones. The 35 malignant lesions were as follows: pancreatic cancer $(3$ cases), adrenal carcinoma ( 3 cases), renal cell carcinoma (3 cases), pleomorphic sarcoma (3 cases), malignant peripheral nerve cell tumor ( 1 case), rhabdomyosarcoma ( 1 case), non-Hodgkin lymphoma (11 cases), metastatic adenocarcinoma (6 cases), seminoma ( 3 cases), Yolk sac tumor (1 case), and Wilms' tumor ( 2 cases). All the 11 cases of nonHodgkin lymphoma were nodal non-Hodgkin lymphomas; therefore extra-nodal malignant lymphoma primary in the retroperitoneum is very rare. A literature search could not find cases of extra-nodal indolent B-cell lymphoma primary in the retroperitoneum, although a case of non-Hodgkin lymphoma of undetermined histology in peritoneum successfully treated by chemotherapy was reported. ${ }^{[2]}$ Also, several cases of diffuse large B-cell lymphoma have been reported. ${ }^{[3,4]}$ Non-Hodgkin lymphoma is now classified according to WHO classification in which lymphomas are roughly classified into $\mathrm{B}, \mathrm{T}, \mathrm{NK}$, null, lymphoblastic, and unclassifiable lymphomas. ${ }^{[5-13]}$ Primary indolent B-cell lymphoma is a category of B-cell lymphoma comprising of follicular lymphoma, mantle cell lymphoma, lympho-plasmacytic lymphoma, mucosa-associated lymphoid tissue (MALT) lymphoma, and small lymphocytic lymphoma/chronic lymphocytic lymphoma. ${ }^{[5-13]}$

\footnotetext{
*Correspondence: Tadashi Terada; Email: piyo0111jp@yahoo.co.jp; Address: Department of Pathology, Shizuoka City Shimizu Hospital, Miyakami 1231 Shimizu-Ku, Shizuoka 424-8636, Japan. 


\section{CASe Report}

A 64-year-old woman presented anuria. The patient did now show evidence for Epstein-Barr (EB) virus infection. Imaging techniques showed a large retroperitoneal mass (see Figure 1). Since retroperitoneal uninvolved lymph nodes were seen, ML was unlikely. No other tumors were seen in the body. No lymphoadenopathy was seen. Needle biopsies of the retroperitoneal tumor were obtained and were subjected to histological and Immunohistochemical studies. Histologically, the biopsy showed a dense proliferation of small lymphoid cells with mild atypia (see Figure 2A-B). The small lymphoid cells showed monotonous proliferation, but very small number of immunoblastic cells were seen in some areas. Plasma cell differentiation was not prominent. No monocytoid cells were seen. Immunophenotypes of the tumor were as follows: cytokeratin (CK) AE1/3 -, CKCAM5.2 -, vimentin +++, CD45 +++, CD20 +++ (see Figure 2C), CD23 ++ (see Figure 2D). CD5 +, CD79a +++, CD138 +/-, bcl-6 -, light chain restriction $+(\lambda \gg \kappa)$ (see Figure 2E), bcl-2 ++ (see Figure 2F), CD45RO -, CD3 -, CD56 -, cyclin D1 -, CD30 -, CD15 -, CD10 -, TdT -, p53 +/-, Ki67 + (see Figure 2G) (labeling index $=8 \%$, KIT -, NSE -, synaptophysin -. EBER for EB-virus was not carried out. A pathological diagnosis of primary retroperitoneal non-Hodgkin lymphoma, indolent B-cell lymphoma, small lymphocytic lymphoma/chronic lymphocytic lymphoma was made. Post-biopsy soluble IL-2 receptor of blood was high $(2,294 \mathrm{U} / \mathrm{ml})$. The patient was treated by chemotherapy (R-CHOP and cisplatin) and radiation, and now the tumor was reduced in size with serums IL-2 receptor of $885 \mathrm{U} / \mathrm{ml}$. The patient was discharged and is now followed up during the period of 12 weeks after the chemotherapy. The R-CHOP therapy was done in 6 courses, one course with R followed CHOP in a week. A total of 50 gray of local radiation was carried out with radiation of 2 gray in a day.

\section{Discussion}

The present retroperitoneal tumor is apparently a lymphoid tumor histologically and immunohistochemically. The histological features are those of indolent B-cell lymphoma. The immunohistology indicated that the tumor was composed by B cells. Positive light chain restriction shows monoclonarity of tumor cells. Indolent B-cell lymphoma consists of the following five: small lymphocytic lymphoma/chronic lymphocytic lymphoma, MALT (marginal zone) lymphoma, lympho-plasmacytic lymphoma, follicular lymphoma, and mantle cell lymphoma. The histological and IHC features are those of small lymphocytic lymphoma/chronic lymphocytic lymphoma. The pattern of CD5, CD20, CD23, CD79a, CD138, bcl-2, cyclinD1, bcl-6 etc, is compatible with that of small lymphocytic lymphoma/chronic lymphocytic lymphoma. The low Ki67 labeling index shows low risk of the tumor.
Figure 1. Pelvic CT shows a large retroperitoneal tumor (arrows)

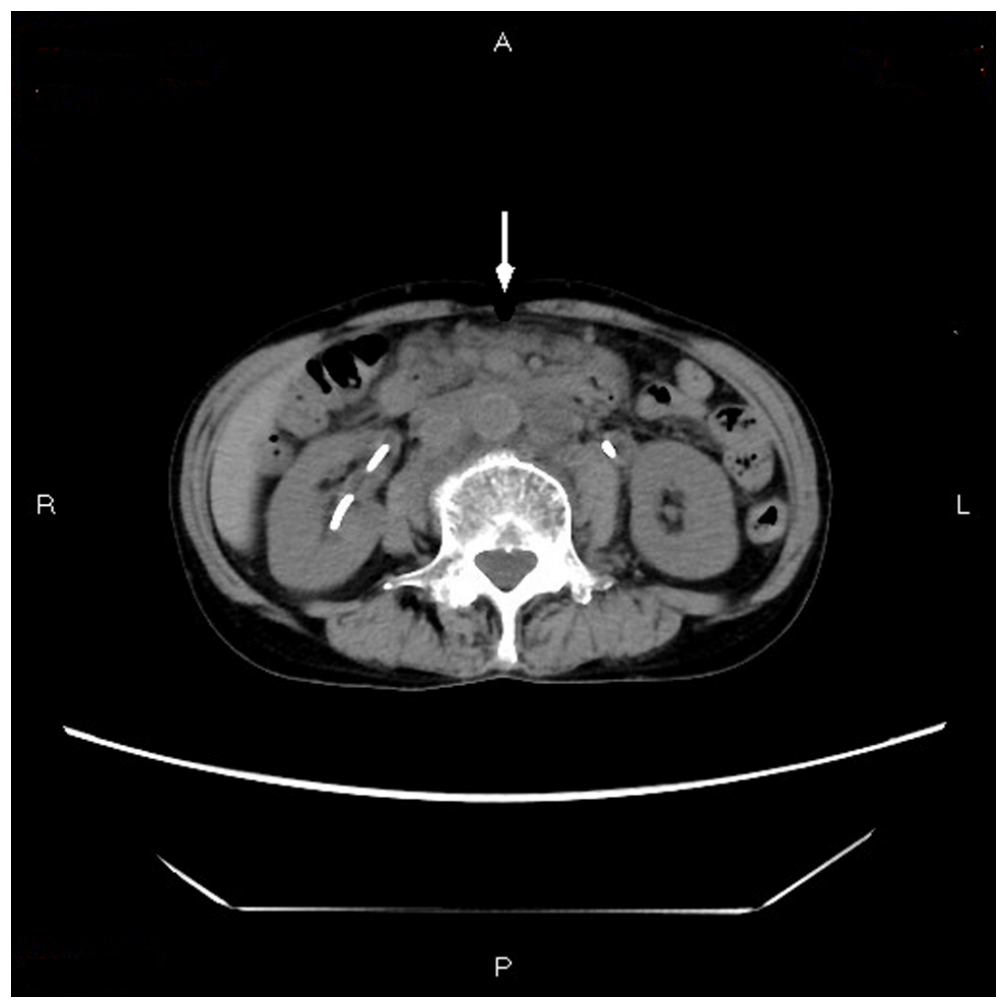



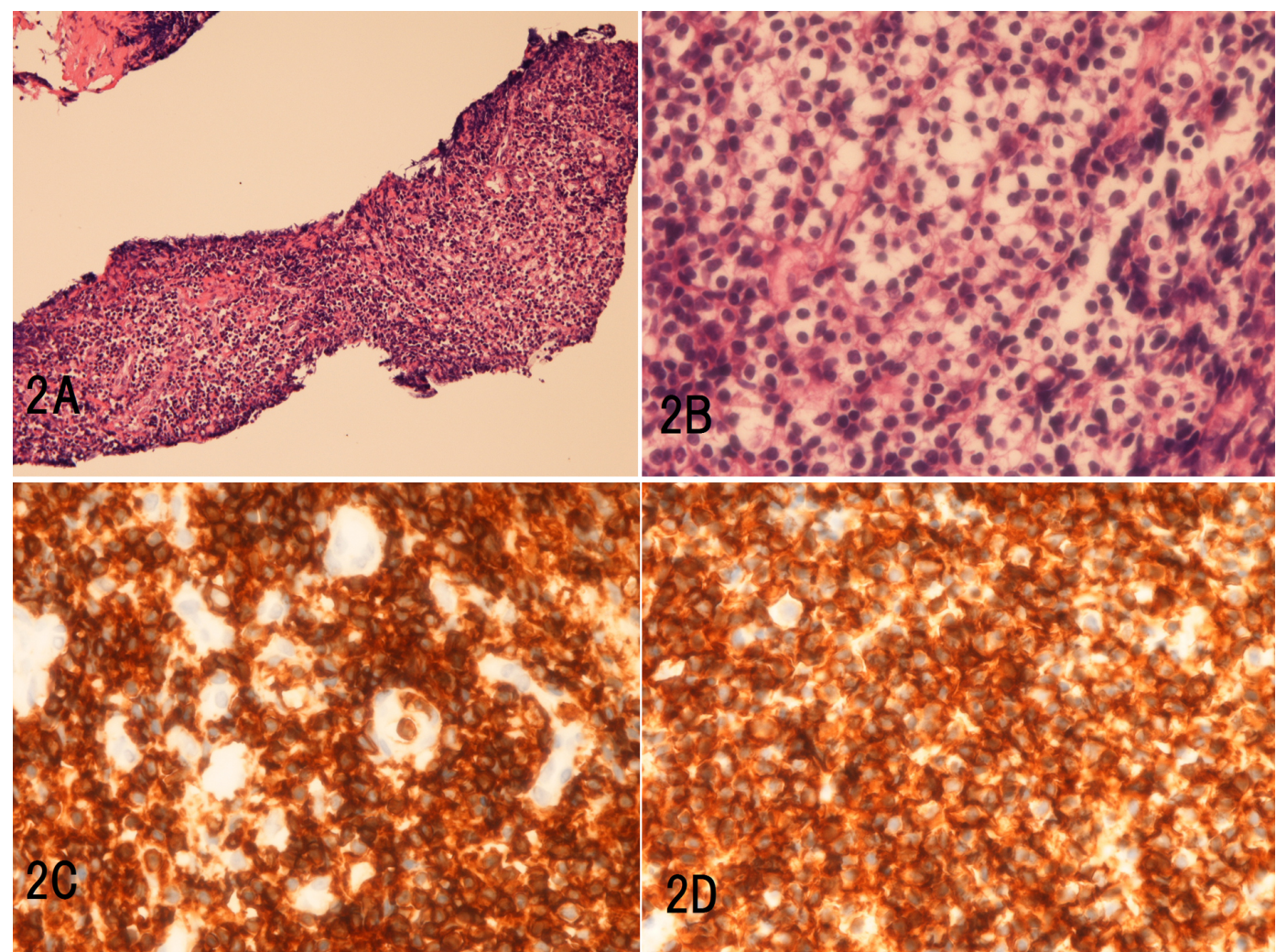

\section{0}
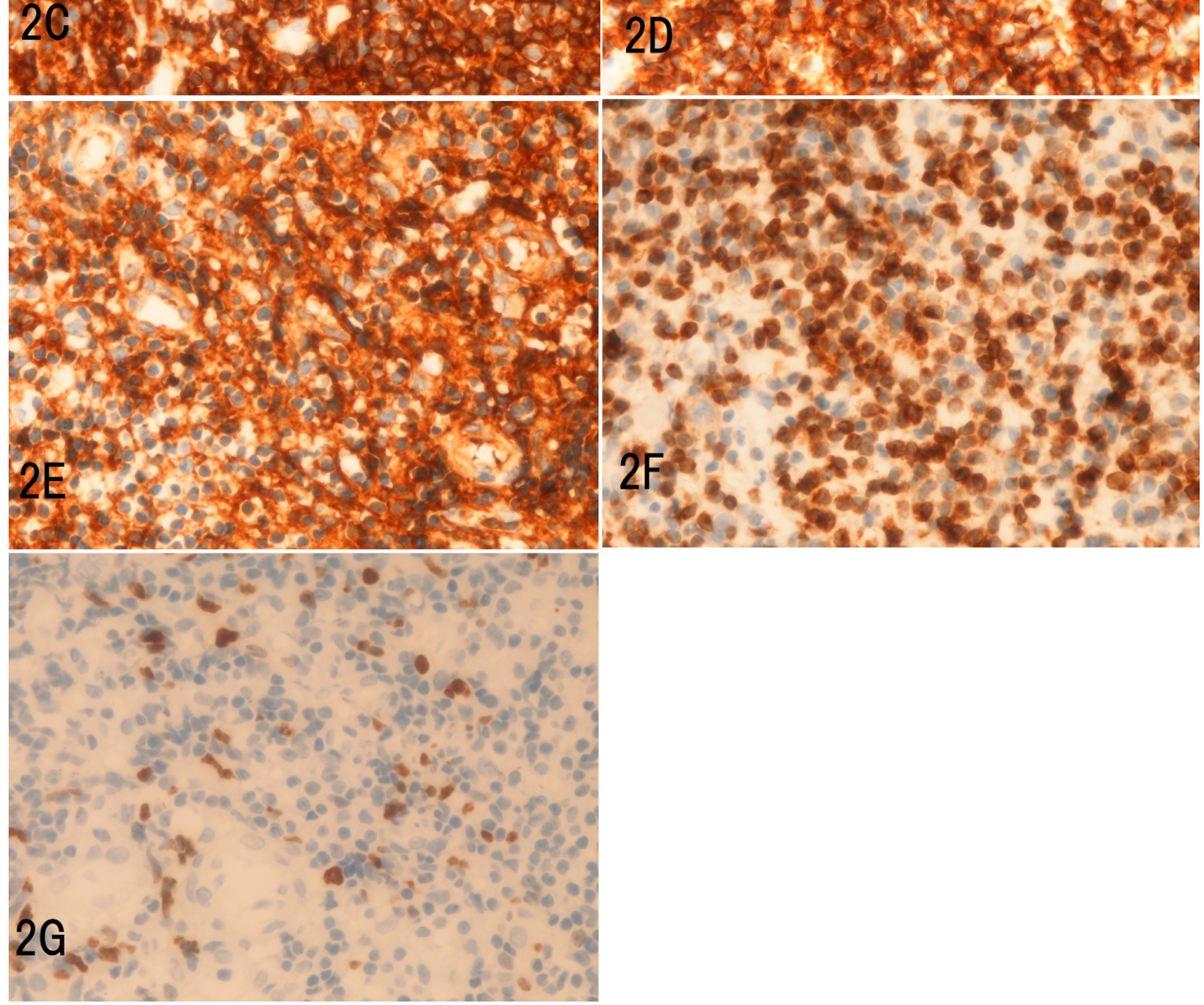

Figure 2. Histological (A,B) and immunohistochemical (C,D,E,F,G) features of the retroperitoneal tumor A: Low power view shows intense proliferation of small lymphoid cells. HE, $\times 40$. B: High power view shows monotonous proliferation of small lymphoid cells with mild hyperchromasia and without obvious nucleoli. $H E, \times 200$. The tumor cells are positive for CD20 (C), CD23 (D), lamda light chain (E), bcl-2 (F), and Ki67 (G: labeling index 8\%). D-G, $\times 200$. 
The present small lymphocytic lymphoma/chronic lymphocytic lymphoma appears primary in Ret, because imaging founded no other tumor and no lymphoadenopathy was noted. The present tumor seemed extra-nodal small lymphocytic lymphoma/chronic lymphocytic lymphoma because no lymphoadenopathy was found and non-involved lymph nodes were seen near the retroperitoneal tumor.

\section{Conclusion}

A very rare case of primary retroperitoneal extra-nodal indolent B-cell lymphoma (small lymphocytic lymphoma/chronic lymphocytic lymphoma) is reported.

\section{CONFlicts OF INTEREST Disclosure}

The author declares no conflict of interest.

\section{REFERENCES}

[1] Chakrabarti I, Bhowmik S, Sinha MG, et al. Ultrasound-guided aspiration cytology of retroperitoneal masses with histopathological corroboration: A study of 71 cases. J Cytol. 2014; 31: 15-9. PMid: 25190978. http://dx.doi.org/10.4103/0970-9371.130629

[2] Fulignati C, Pantaleo P, Cipriani G, et al. An uncommon clinical presentation of retroperitoneal non-Hodgkin lymphoma successfully treated with chemotherapy: a case report. World J Gastroenterol. 2005; 11: 3151-5. PMid: 15918208. http://dx.doi.org/10.37 48/wjg.v11.i20.3151

[3] Pileri SA, Zinzani PL, Ascani S, et al. Diffuse large B-cell lymphoma with primary retroperitoneal presentation: clinico-pathologic study of nine cases. Ann Oncol. 2001; 12: 1445-53. http://dx.doi.o $\mathrm{rg} / 10.1023 / \mathrm{A}: 1012559725243$

[4] Cai YL, Xiong XZ, Lu J, et al. Non-Hodgkin's lymphoma with uncommon clinical manifestations: A case report. Oncol Lett. 2015; 10 : 1686-8. PMid: 26622732.

[5] Swerdlow SH, Berger F, Pileri SA, et al. Lymphoplasmacytic lymphoma. In: Swerdlow SH, Campo E, Harris NL, Jaffe ES, Pileri SA, Stein H, Thiele J, Vardiman JW eds. WHO classification of tumours of haematopoietic and lymphoid tissues. IARC: Lyon; 2008. 194-6p.

[6] Terada T. Gastrointestinal malignant lymphoma: a pathologic study of 37 cases in a single Japanese institution. Am J Blood Res. 2012; 2 :
194-200. PMid: 23119230.

[7] Terada T, Shitakashi Y, Sugiura M. T-cell lymphoma of the penis as the first manifestation of adult T-cell lymphoma/leukemia. Int $\mathrm{J}$ Dermatol. 2012; 51: 973-5. PMid: 22788817. http://dx.doi.o $\mathrm{rg} / 10.1111 / \mathrm{j} .1365-4632.2011 .05086 . \mathrm{x}$

[8] Terada T. One patient with two lymphoma; simultaneous gastric MALT lymphoma and ileal diffuse large B-cell lymphoma. Int J Clin Exp Pathol. 2012; 5: 260-3. PMid: 22558482.

[9] Terada T. Primary diffuse large B-cell lymphoma of the submandoibular gland. Int I Clin Exp Pathol. 2012; 5: 179-81.

[10] Terada T. Acute onset pyothorax-associated lymphoma (PAL) with inflammatory features. Int J Clin Exp Pathol. 2012; 5: 163-6. PMid: 22400078.

[11] Terada T. TDT (-), KIT (+), CD34 (+), CD99 (+) precursor T lymphoblastic leukemia/lymphoma. Int J Clin Exp Pathol. 2012; 5: 16770. PMid: 22400079.

[12] Terada T. Primary diffuse large B-cell lymphoma of the ethmoid sinus. Int J Clin Exp Pathol. 2011; 4: 799-801. PMid: 22135730.

[13] Terada T. CD5-positive marginal zone B-cell lymphoma of the mucosa-associated lymphoid tissue (MALT) of the lung. Diagnostic Pathology. 2012; 7: 16. PMid: 22333190. http://dx.doi.org/1 $0.1186 / 1746-1596-7-16$ 